\title{
A (des)construção do mito de Hitler: paixões aristotélicas e teorias nietzschianas em uma animação do pernalonga
}

\section{Cláudia Borragini Abuchaim Leonardo Vinícius de Souza Tavares}

A paixão sem a razão é cega, a razão sem a paixão é inativa. Baruch Spinoza

\section{Considerações Iniciais}

S omos seres retóricos e passionais, por mais que a racionalidade nos habite, $\mathcal{S}$ são as paixões que nos movem. No início do século XX, o sociólogo Maurice Halbwachs ${ }^{1}$ ao analisar a importância da memória, cunhou o termo "memória coletiva", que em síntese, procurou despertar nas pessoas a sensação de pertencer a um determinado grupo por ter vivenciado os mesmos "momentos históricos". O compartilhamento da memória torna-se mais prazeroso, segundo Halbwachs, ${ }^{2}$ pois a lembrança evocada por várias pessoas suscitará maior confiança na exatidão de uma mesma experiência.

No presente capítulo, propomos aos leitores uma viagem ao passado. Há oitenta anos, o coelho Pernalonga habita a "memória coletiva" da sociedade. Estreou em 27 de julho de 1940. As animações, a princípio, estimulam o uni-

\footnotetext{
1 Maurice Halbwachs, sociólogo francês, discípulo de Émile Durkheim, escreveu seus principais trabalhos entre os anos de 1920 e 1940.

2 Halbwachs, 1990
} 
verso infantil e, na idade adulta, podemos reconstruir e vivificar o passado, ressignificando-o.

Nossos estudos voltaram-se à análise do curta-metragem do Pernalonga, traduzido como O Coelho e os Nazistas, com o título original de Herr Meets Hare (O Senhor Conhece a Lebre, em tradução livre), feito em 1945, durante a Segunda Guerra Mundial. A animação, em nossa perspectiva, se apresentou como obra de arte, pois é rica em simbologias e em alusões históricas.

Aristóteles, no livro II da Retórica, ${ }^{3}$ avalia que as paixões levam os homens a mudar suas opiniões e seus julgamentos: paira no enredo da animação o temor e a confiança. Em um perspicaz jogo retórico e cênico - quinésico e proxêmico -, as paixões se alternam e as simbologias e metáforas conduzem a uma trajetória fascinante pela história da mitologia, da música, da política, em um universo cujo maestro é o coelho Pernalonga.

Quanto à metodologia, no âmbito da Retórica, nos ancoramos em Aristóteles (2003, 2012). Na análise filosófica, escolhemos Nietzsche (2014): a construção/ desconstrução do mito de Hitler nos dirigiu à teoria do "filosofar com o martelo". Os desenhos animados a priori nos proporcionam diversão e entretenimento, ligado ao "espírito dionisíaco", mas o episódio analisado também ilustra o "espírito apolíneo".

Aristóteles propõe, em seu esquema retórico, a identificação de três provas de persuasão fornecidas pelo discurso: o ethos, o pathos e o logos. Por serem as paixões o movimento condutor do enredo da animação, priorizamos o pathos em nossa análise.

\section{Paixão, a etimologia}

Segundo Bordelois, ${ }^{4}$ não há uma raiz lexical indo-europeia para designar a palavra "paixão", pois nas línguas primitivas não havia diferenciação entre emoção e paixão. A ideia de paixão foi construída a partir de quatro grupos de coincidências específicas: ${ }^{*}$ eis, ${ }^{*}$ men, furor, ${ }^{*}$ werg.

${ }^{\star}$ Eis indicava a coexistência do veloz, do divino e do passional. Em Crátilo, ${ }^{5}$ discute a terminologia de theoi, palavra grega que significa deuses. Observa o filósofo que os bárbaros reconheciam os astros como deuses, pois se deslocavam e corriam (thein) pelo céu à noite, assim como Apolo cavalgava com a carruagem

3 Sobre a composição final dessa obra, dividida em três livros, Quintín Racionero (tradutor de Aristóteles diretamente do grego para o espanhol) explica que se deu a partir de 355 a.C., durante a segunda estada de Aristóteles em Atenas

4 Bordelois, 2007

5 Platão, 2001 
A (des)construção do mito de Hitler: paixões aristotélicas e teorias nietzschianas em uma animação do pernalonga

do Sol. Nas línguas clássicas, como no grego, tem-se a raiz hieros, que significa o sagrado, o que é tocado ou invadido pelos deuses. Apresenta as seguintes derivações: hierático (sagrado), hierofante (sacerdote), hierarquia (ordem), hieróglifo (signo sagrado esculpido).

Assim como ieros, a palavra Ira também descende do aspecto divino de eis. Citamos como exemplo a diferenciação entre Ira e Cólera. Na Ilíada, ${ }^{6}$ Homero apresenta a Cólera de Aquiles e a Ira dos deuses. A Ira que causa a Guerra de Tróia é divina e justificada, a Cólera de Aquiles é pura paixão humana motivada pela vingança.

A Ira se apresenta em várias passagens do Antigo Testamento como expoente máximo do Deus hebraico, justificada em quaisquer situações, seja contra seu próprio povo ou contra seu inimigo.

Da raiz indo-europeia * men deriva a palavra menes, do grego Cólera. Homero utiliza, na Ilíada, a Cólera de Aquiles como mote principal que moverá toda a ação em sua epopeia. Na Retórica das Paixões, ${ }^{7}$ Aristóteles afirma que o encolerizado sente prazer ao vingar-se e regozija-se ao obter o que deseja, pois só deseja o que lhe é possível. Do vocábulo menes também deriva o verbo mainomai, que significa enraivecer-se, irritar-se, experimentar mania, loucura, raiva.

Segundo Ernout e Meillet, ${ }^{8}$ do furor descende o vocábulo fúria, que vem do verbo furo, furio, que significa estar louco, fora de si, perdido, furioso, alienado, em grego mainomai.

Bordelois 9 afirma que "na raiz ${ }^{\star}$ werg, convivem passionalmente a cólera e a sexualidade, além de uma evidente relação com o sagrado". A autora cita o dicionário Watkins e define * werg: descende do grego ergon, que compõe a palavra energia e significa obra, ação; organon (órgão); orgia.

A orgia grega relacionava-se às festas de Baco, cerimônias religiosas que utilizavam o vinho e a música para incitar o transe e a comunhão com o divino. Portanto, a paixão é transcendente, compartilhada por deuses e homens.

\section{Paixões Aristotélicas}

Na Retórica das Paixões, ${ }^{10}$ Aristóteles afirma que "as paixões são todos aqueles sentimentos que, causando mudança nas pessoas, fazem variar seus julgamentos, e são seguidos de tristeza e prazer, como a cólera, a piedade, o temor

\footnotetext{
Homero, 2018

Aristóteles, 2003

Ernout; Meillet, 1939

Bordelois, 2007, p. 54

10 Ibid., p.5
} 
e todas as outras paixões análogas, assim como seus contrários". Paixões (pathe) são sentimentos ligados ao prazer (hedoné) ou à dor (lúpe), associadas ao agir humano e mantêm estreita relação com a virtude (areté) ou com o vício (kakía).

Incitadas pelo orador (ethos), as paixões são condições transitórias. Aristóteles assim as apresenta em sua Retórica ${ }^{11}$ : ira e calma, amizade e inimizade, temor e confiança, vergonha e desvergonha, amabilidade e indelicadeza, piedade e indignação, inveja e emulação. ${ }^{12}$

As paixões conduzem a tomadas de posições, por serem transitórias, por vezes, inquietam mentes brilhantes, como é o caso do filósofo, filólogo, crítico cultural, poeta e compositor prussiano Nietzsche. Para Curt Paul Janz,

O pensamento de Nietzsche foi musical na medida em que foi fortemente emocional, nascido da vivência do momento - não obstante toda a agudeza do intelecto. Sua musicalidade influi também na configuração, na forma de seus escritos, o que por outro lado determina sua relação com a música. ${ }^{13}$

Segundo Nietzsche, é a música que liberta o espírito, seu pensamento foi musical, o filósofo conduziu sua vida movido pelas paixões.

\section{Nietzsche, Ecce Homo}

Friedrich Wilhelm Nietzsche ${ }^{14}$ nasceu em 15 de outubro de 1844, em Rökken (Prússia, atual Alemanha), de família luterana, foi preparado para ser pastor. Batizado como Friedrich Wilhelm em homenagem ao rei da Prússia, na idade adulta abandonou o nome do meio. Aos 14 anos, foi selecionado para bolsa na aclamada escola de Pforta, na qual estudaram o filósofo romântico Fichte (1762-1814) e o poeta Novalis (1772-1801). Leitor voraz, dedicou-se às leituras de Schiller (1759-1805), Byron (1768-1824), Goethe (1749-1832), entre outros.

O Romantismo teve suma importância na formação intelectual juvenil de Nietzsche, que na maturidade, refutou-o. Ao adquirir fluência em grego e latim,

11 Id., 2012, p. XXXIV

12 Não nos deteremos a definir cada paixão, deixaremos tais definições aflorarem no corpus da análise de nosso objeto de estudo

13 Entrevista de Curt Paul Janz no posfácio de O caso Wagner e Nietzsche contra Wagner (NIETZSCHE, 1999, p.107)

14 Todas as referências biográficas de Nietzsche foram consultadas na COLEÇÃO OS PENSADORES, Nietzsche, 1999 
A (des)construção do mito de Hitler: paixões aristotélicas e teorias nietzschianas em uma animação do pernalonga

contestou os ensinamentos do cristianismo. Desalentado com a fé, rompeu com a religiosidade e passou por um período libertino.

Terminados os estudos em Pforta, foi para Bonn estudar filosofia e teologia. Aluno brilhante, conquistou a cátedra de filologia clássica na Universidade de Basileia, com apenas 24 anos. Escreveu A Origem e Finalidade da Tragédia em 1871, seu primeiro trabalho acadêmico.

Conheceu o maestro e compositor Richard Wagner com quem manteve laços de estreita amizade. Em busca de inspiração, refugiou-se na casa de campo do músico, localizada nas imediações do lago de Lucerna, em Tribschen. Influenciado por Wagner e Schopenhauer, publicou seu primeiro livro O Nascimento da Tragédia no Espírito da Música (1872).

Precisou interromper sua carreira universitária devido a um quadro fisiológico debilitado: crises constantes de cefaleia, dificuldade para se expressar e problemas de visão. Tentou retomar a vida acadêmica, mas com severos problemas em suas cordas vocais, sua fala ficou quase inaudível.

Em 1879, devido à debilidade visual, abandonou a universidade. Data desse período, a edição de seus principais livros; a consagração de sua obra efetivou-se apenas no final do século XIX, próximo a sua morte.

Conhecer, apaixonar-se e ser rejeitado por Lou Andréas Salomé,${ }^{15}$ agravou o estado de solidão do filósofo. Os sinais de demência apareceram na última década de vida, quando começou a escrever cartas para várias pessoas e assinar como "Dionísio" e "O Crucificado". Internado na Basileia, foi diagnosticado com paralisia cerebral progressiva e faleceu em 25 de agosto de 1900.

\section{Nietzsche, Ecce Philosophos}

A carreira filosófica de Nietzsche apresenta perspectivas variadas e retomadas de ideias em seus diversos livros. Reconhecemos que não há como periodizar cronologicamente sua obra com o intuito de apresentar uma leitura linear de sua filosofia.

Influenciado por Arthur Schopenhauer e Richard Wagner, se apoiou no Idealismo Alemão. O encantamento com Wagner deu-se pelo viés intelectual, ambos admiravam o filósofo Schopenhauer e estudavam a Grécia Antiga. A obra O Mundo como Vontade e Representação de Schopenhauer inspirou os primeiros pensamentos filosóficos de Nietzsche. Posteriormente, rompeu com

15 Lou Andréas Salomé foi filósofa, poeta, romancista, ensaísta e psicanalista (FÉRES; CHAUÍ, 1999) 
o niilismo filosófico de Schopenhauer que apresentava a "vontade culpada", converteu-a em "vontade alegre".

Nietzsche estudou a Grécia Antiga e a Música, compôs obras como O Drama Musical Grego (1870), O Nascimento da Tragédia no Espírito da Música (1872), A Filosofia na Idade Trágica dos Gregos (1873/1874). Interessou-se, principalmente, pelos filósofos pré-socráticos, pela espontaneidade em aliarem o pensar e o viver. Escreveu sobre Ésquilo, Eurípides, Tales, Anaximandro, Sócrates, Platão.

Wagner leu Aristófanes e Homero, mas impressionou-se com as obras de Ésquilo, tencionava escrever um drama musical sobre Aquiles. Influenciado pelo ufanismo alemão e pelas sagas nórdicas, baseou-se no poema épico do século XIII, Nibelungenlied, e escreveu Der Ring des Nibelungen (1848 a 1874). ${ }^{16}$

Tanto Nietzsche quanto Wagner discorreram sobre os elementos apolíneo e dionisíaco na tragédia grega. Nietzsche os apresentou em O Nascimento da Tragédia (1872), enquanto Wagner os abordou em Arte e Revolução (Die Kunst und die Revolution, 1849).

A postura política e religiosa de Wagner foi o motivo de rompimento com Nietzsche. Inicialmente, ligado às ideias anarquistas de Bakunin e Proudhon, o compositor celebrou a união com o Estado depois da formação do Segundo Reich $^{17}$ em 1871. Publicou panfletos antissemitistas, renunciou ao judaísmo, converteu-se ao cristianismo. ${ }^{18}$

Em seu último ano de lucidez (1888), Nietzsche escreveu um ensaio crítico intitulado Nietzsche contra Wagner (publicado em 1895). Nesse texto, o filósofo expõe os motivos do rompimento com Wagner:

(...) Wagner foi uma de minhas doenças. Não que eu deseje me mostrar ingrato a essa doença. Se nestas páginas eu proclamo a tese de que Wagner é danoso, quero do mesmo modo proclamar a quem, não obstante, ele é indispensável - ao filósofo. Outros poderão passar sem Wagner; mas o filósofo não pode ignorá-lo. Ele tem de ser a má consciência do seu tempo - para isso, precisa ter a sua melhor ciência. ${ }^{19}$

O legado filosófico de Nietzsche é extenso, complexo, apaixonado, irreverente. Apresentamos, em síntese, suas principais abordagens filosóficas. ${ }^{20}$

\footnotetext{
16 Ellis, 1904

17 Reich Alemão era o nome oficial para o Estado-Nação alemão no período de 1871 a 1943 . Traduzido literalmente em português para "Império Alemão" (EVANS, 2012)

18 Patriota, 2013

19 Nietzsche, 2014, p. 10

20 As considerações se baseiam no estudo do livro Friedrich Nietzsche Obras Incompletas, 2014
} 
A (des)construção do mito de Hitler: paixões aristotélicas e teorias nietzschianas em uma animação do pernalonga

- Em Humano, Demasiado Humano (1878) rompe com toda a tradição dogmática e metafísica. Escrita em 638 aforismos, a obra desconstrói a imagem do santo, do herói, do gênio e apresenta a teoria da moral de rebanho. Critica Schopenhauer por seu niilismo, que influenciará Wagner, que também é condenado por seus ideais cristãos, nacionalismo alemão e antissemitismo exacerbado. A crítica ao cristianismo será retomada em O Anticristo (1888).

- Em A Gaia Ciência (1882), proclama a "morte de Deus", apresenta a ideia do "eterno retorno", a figura mítica de Zaratustra e a morte da experiência do sagrado entre os homens modernos. Atribui importância primordial à vida e cunha o termo amor fati (amor ao destino).

- Em Assim Falou Zaratustra (1885), encontra-se a síntese de toda a concepção filosófica nietzschiana de transvaloração dos valores.

- Em Além do Bem e do Mal (1886), propõe uma transvaloração dos valores, engendra uma busca pelo übermensch (super-homem), que rompe com o maniqueísmo social, que cria seus próprios valores afirmativos de vida, por isso, estará "além do bem e do mal". A mesma transvaloração dos valores é encontrada em A Genealogia da Moral (1887), por meio de seu método genealógico, investiga-se a origem dos valores, para aceitação ou refutação dos mesmos.

- Em O Crepúsculo dos Ídolos ou Como Filosofar com o Martelo (1888), a desconstrução dos modelos e das verdades - por isso "filosofar com o martelo"- propõe questionar as convicções e criar seus próprios valores, sem se submeter às ideias prontas. O sentido iconoclasta de sua "filosofia do martelo" influenciou o movimento Dadaísta e outras vanguardas do início do século XX.

- Ecce Homo (1888) é uma autobiografia na qual sintetiza sua obra e expõe seus conflitos existenciais.

As teorias nietzschianas propõem uma transvaloração dos valores, questionam as convicções, incitam à criação e à diversificação de ideias. Elas nasceram das paixões de um homem que vivenciou o século XIX. Sua aplicabilidade se apresenta como um caleidoscópio. Podemos analisá-las em qualquer vertente de arte, escolhemos a animação do Pernalonga, por incitar paixões em várias gerações.

A importância do coelho se apresenta desde seu nascimento, momento em que uma grande equipe de profissionais se dedicou à sua criação. Muito além 
de simples animação, Pernalonga ocupa lugar de importância na memória coletiva de vários países.

\section{Quem é o Pernalonga?}

Pernalonga é um personagem de animação criado pela Warner Bros., como parte da série de curtas animados Looney Tunes. ${ }^{21}$ É considerado uma das maiores estrelas da era de ouro da animação americana (que vai de 1928 até meados de 1960).

O coelho foi concebido nas unidades de animação de Leon Schlesinger nos estúdios da Warner Bros., que continha grandes nomes da animação como Tex Avery, Chuck Jones, Bob Clampett e Friz Freleng, assim como o renomado dublador Mel Blanc e o músico Carl Stalling.

O processo de criação envolveu uma combinação de inspirações: Robert McKimson desenhou a folha modelo, Freleng desenvolveu sua personalidade, Avery e Jones o refinaram e Blanc deu voz à personagem, que apesar de aparecer em alguns curtas desde 1938, debutou oficialmente, com a forma que conhecemos hoje, em 1940, na animação A Wild Hare (Uma Lebre Selvagem, em tradução livre).

Nas primeiras animações, Pernalonga era identificado como Happy Rabbit (Coelho Feliz). Concebeu-se o nome original em homenagem a seu animador Ben "Bugs" Hardaway, que propôs um esboço para a personagem, que foi nomeado "Bugs' Bunny" (Coelho do Bugs) pela equipe de criadores. Assim, o coelho herdou o apelido de seu criador. Em cada país, é chamado por um nome diferente, no Brasil é Pernalonga. Seus quadrinhos foram publicados por quase 50 anos, de 1943 a 1990.

Seu jeito irreverente, sarcástico, debochado e piadista foi inspirado em personalidades como Charlie Chaplin, Groucho Marx e Clark Gable. ${ }^{22}$ Reconhecido por sua célebre frase What's up, Doc? (em português adaptada para "O que é que há, velhinho?"), Pernalonga foi indicado ao Oscar três vezes e contemplado com a estatueta pela animação Knighty-Knight Bugs (1958).

Em 1985, Pernalonga ganhou uma estrela na Calçada da Fama de Hollywood, fato inédito nas animações da Warner Bros. Em 1992, sua importância elevou-se ao ser adicionado ao Registro Nacional de Filmes da Biblioteca do Congresso,

21 Todas as informações do subtítulo “Quem é o Pernalonga?" estão em THE NEW Encyclopaedia Britannica: Micropaedia, 1986.

22 A inspiração do Clark Gable surgiu da cena do filme Aconteceu Naquela Noite, na qual o ator aparece sentado numa cerca comendo uma cenoura enquanto tenta conquistar uma moça (SANDLER, 1998) 
A (des)construção do mito de Hitler: paixões aristotélicas e teorias nietzschianas em uma animação do pernalonga

pela adaptação de Der Ring des Nibelungen de Richard Wagner em What's Opera, Doc? (1957).

\section{Pernalonga: Um Breve Ensaio}

Após uma extensa análise e estudo da filmografia do Pernalonga, constatamos que muito além de simples entretenimento, o coelho tornou-se mascote nacional dos Estados Unidos da América (EUA), na época da Segunda Guerra Mundial (1939-1945). Desde dezembro de 1941, os estúdios da Warner Bros. e da Walt Disney trabalharam em animações para propaganda militar. ${ }^{23}$

Selecionamos, para nossa análise, o curta-metragem O Coelho e os Nazistas ${ }^{24}$ (1945), com o título original de Herr Meets Hare (O Senhor Conhece a Lebre, em tradução livre).

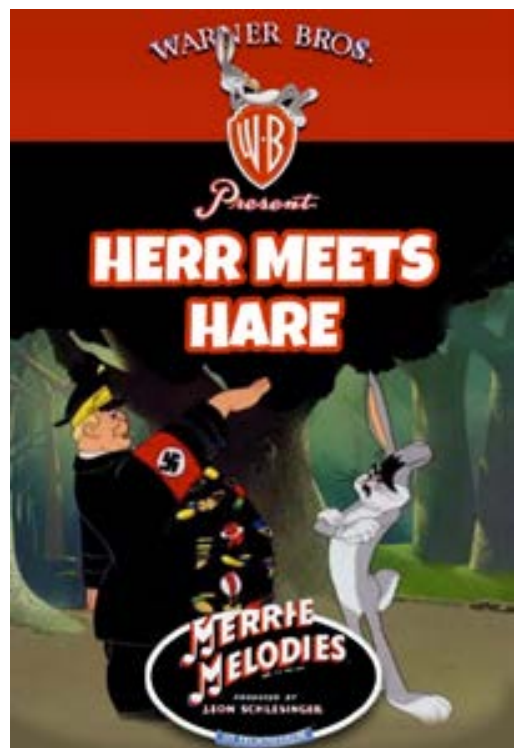

Figura 1: Capa da animação

23 Shull; Wilt 2004

24 A animação faz parte da série Merrie Melodies, dirigida por Friz Freleng. Lançada em 13 de janeiro de 1945, pouco antes da queda do Terceiro Reich, foi o penúltimo cartoon com temática de guerra lançado pela Warner Bros., quatro meses antes do "Dia da Vitória na Europa" - dia em que aconteceu o aceite formal dos Aliados da Segunda Guerra Mundial. A rendição da Alemanha, em 8 de maio de 1945, marcou o fim da Segunda Guerra Mundial na Europa (MASSON, 2010) 
Aristóteles, na Retórica, ${ }^{25}$ afirma que o discurso retórico busca os meios de persuasão sobre qualquer questão dada. O primeiro ponto a se desvendar em uma análise discursiva é a intencionalidade do texto. Na animação, percebese que o auditório (o espectador), na época do lançamento do vídeo (1945), vivia os horrores da Segunda Guerra Mundial. Em nossa análise, resgatamos o contexto histórico, talvez desconhecido pelo nosso auditório do século XXI. A linguagem não-verbal (proxêmica e quinésica) da animação contribuiu com os meios de persuasão, que variaram de acordo com a cena, em um jogo, no qual, constantemente, as paixões se invertiam.

Aristóteles ${ }^{26}$ apresenta o sistema retórico composto por quatro partes: inventio, dispositio, elocutio, actio. Reboul ${ }^{27}$ ressalta a importância da memória (mnemé), "que para certos autores latinos constituía a quinta parte da retórica: a arte de memorizar o discurso". Nossa análise perscrutou a actio na proferição do discurso, incluindo os gestos, as mímicas e a dicção do orador como se fosse um ator.

Percebemos, na comparação da análise do roteiro original em língua inglesa para a adaptação em língua portuguesa, algumas variações, que ligadas às provas intrínsecas do texto, por vezes, comprometeram a intencionalidade da animação. Optamos por acrescentar, quando necessário, a tradução do roteiro da animação original.

A animação começa com uma narração ao estilo de Walter Winchell, famoso narrador de rádio americano judeu, que fez as primeiras propagandas antinazistas, atacou Hitler e organizações americanas pró-facistas e pró-nazistas. ${ }^{28}$

Na versão dublada, o narrador comenta: "Com a Alemanha derrotada, todos fazem a pergunta de 64 dólares, onde está Göring? Obtive informações de que ele tentava relaxar das pressões que sofria caçando na Floresta Negra.. No original, ao questionar o paradeiro de Hermann Göring, o narrador ironicamente utiliza o apelido dado pelos soldados aliados "Fatso" (gordo) para referir-se ao militar de alta patente: "Fatso" Göring.

Segundo Aristóteles, ${ }^{29}$ "persuade-se pela disposição dos ouvintes, quando estes são levados a sentir emoção por meio do discurso, pois os juízos que emitimos variam conforme sentimos tristeza ou alegria, amor ou ódio". A figura de Göring incita paixões no espectador norte-americano e no brasileiro. 
A (des)construção do mito de Hitler: paixões aristotélicas e teorias nietzschianas em uma animação do pernalonga

O despertar das paixões por atos bárbaros levou os Estados Unidos da América (EUA) e o Brasil a participarem da Segunda Guerra Mundial. Grande parte da população estadunidense conhece o incidente de Pearl Harbor, amplamente divulgado pela mídia. Por razões político-econômicas, aconteceu o ataque: os Estados Unidos eram um obstáculo para a expansão japonesa no Oceano Pacífico. Em 7 de dezembro de 1941, o Japão, comandado por Chuichu Nagumo, atacou Pearl Harbor, a principal base naval dos EUA no Havaí. Matou mais de dois mil americanos e mudou a opinião pública. O país, então, decidiu entrar na Segunda Guerra Mundial. Assim, "a realidade mostrou que o ataque de Nagumo bastou para chocar, ferir e enfurecer os americanos, mas não para prejudicar sua capacidade de guerra. Foi, portanto, uma operação muito mal concebida". ${ }^{30}$

Os EUA movidos pela cólera e pela vingança decidiram entrar na guerra. A cólera é uma das paixões de Aristóteles, ${ }^{31}$ que assim a define:

Seja, então, a cólera o desejo, acompanhado de tristeza, de vingar-se ostensivamente de um manifesto desprezo por algo que diz respeito a determinada pessoa ou a algum dos seus, quando esse desprezo não é merecido. (...) a toda cólera se segue certo prazer, proveniente da esperança de vingar-se.

O Brasil compartilhava dessa paixão, em 1942, pois os alemães e os italianos, ao tomarem ciência da aproximação do Brasil com os EUA, começaram a promover retaliações contra o país. Durante a Segunda Guerra Mundial, trinta e quatro embarcações brasileiras foram torpedeadas, causando a morte de 1.081 pessoas, a maioria, civis inocentes. Em 15 de agosto de 1942, o navio Baependi, com 306 pessoas a bordo foi torpedeado, apenas 36 sobreviveram. O episódio construiu uma cena trágica quando os cadáveres e destroços chegaram ao litoral nordestino. O submarino alemão, U-507, em menos de cinco dias, entre 15 e 19 de agosto de 1942, afundou mais seis navios brasileiros na costa do Nordeste. Alguns historiadores consideram essa investida o "Pearl Harbor brasileiro". O país, movido pela paixão da cólera, cobrou do então presidente Getúlio Vargas um posicionamento. Cinco dias depois, o Brasil declarava guerra à Alemanha e a seus aliados. ${ }^{32}$

Os dados históricos apresentam os motivos de a animação mover paixões nas duas nações. Meyer, ao discorrer sobre as paixões em Aristóteles, observa que:

30 Hastings, 2012, p. 211

31 Aristóteles, 2003, p. 7

32 Sander, 2007 
(...) os homens são diferentes, mas compartilham a busca política, isto é, a preocupação de encontrar um Bem comum definido como ordem pública. (...) Mas, apesar de humano, o animal político afirma sua identidade, no dizer de Aristóteles. Nesse sentido a barbárie, queiramos ou não, não poderia ser "inumana", o que obriga a compreendê-la para poder condená-la. ${ }^{33}$

Retornemos à análise: a cena corta para a Floresta Negra, localizada no sudoeste da Alemanha, famosa por abrigar o Führerhauptquartier Tannenberg (também chamada “Instalação T”), um dos Quartéis-Generais do Führer, construído, em 1939, para ser usado como uma instalação militar de comando e controle de Adolf Hitler. Estava localizado perto da cidade de Freudenstadt, dentro da Floresta Negra, onde Hitler passou cerca de uma semana, em 1940, enquanto inspecionava a fortaleza que formava a Linha Maginot. ${ }^{34}$

Os protagonistas da animação são Hermann Göring e Pernalonga. Para melhor compreensão do leitor, faz-se necessário um breve olhar bibliográfico para a figura histórica do alemão.

Hermann Göring foi uma das figuras mais famosas do partido nazista, veterano da Primeira Guerra Mundial, o último comandante da unidade Jagdgeschwader I, anteriormente comandada por Manfred von Richthofen, “o Barão Vermelho". Em 1933, como Ministro Interino, fundou a Gestapo. Nomeado para comandante-chefe da Luftwaffe, a força aérea alemã, em 1935, uma posição que manteve até o final da Segunda Guerra Mundial. Em 1940, Adolf Hitler promoveu-o ao posto de Reichsmarschall, ${ }^{35} \mathrm{o}$ mais elevado em relação aos outros comandantes da Wehrmacht. ${ }^{36}$ Em 1941, era o segundo na hierarquia nazista, nomeado como sucessor e assessor de Hitler em todos os gabinetes. Sua relação com o Führer fragilizou-se com a incapacidade da Luftwaffe de proteger as cidades alemãs dos bombardeamentos dos Aliados e de reabastecer as forças do Eixo cercadas em Stalingrado. Göring retirou-se quase por completo da cena política e militar e, concentrou-se na compra de propriedades e de arte, grande parte das quais roubadas das vítimas judaicas do Holocausto. ${ }^{37}$ É nesse momento histórico que

33 Michel Meyer prefaciou a obra Retórica das Paixões, no entanto, a profundidade da análise se apresenta como um ensaio da obra aristotélica (MEYER, p. XXXVII)

34 Ligne Maginot: construída pelos franceses para preservar suas fronteiras com a Alemanha e a Itália, após a Primeira Guerra Mundial, invadida e utilizada pelos nazistas, durante a Segunda Guerra Mundial (EVANS, 2012)

35 Reichsmarschall: em alemão, marechal do Reich, mais alta patente das Forças Armadas do Sacro Império Romano-Germânico e da Alemanha Nazista (HASKEW, 2011)

36 Wehrmacht: Forças Armadas Unificadas da Alemanha Nazista (TAYLOR, 1995)

37 Frischauer, 1951 
A (des)construção do mito de Hitler: paixões aristotélicas e teorias nietzschianas em uma animação do pernalonga

Göring é representado na animação. A figura do alemão evocava Hitler, por isso, despertava no auditório, paixões incitadas pelo nazismo.

Na próxima cena, Göring veste um típico estereótipo de roupa alemã (lederhosen) e marcha junto com um cão durante uma caçada. De repente, o cachorro para e aponta para sulcos na terra, de onde sai Pernalonga. Visivelmente perdido e na frente de uma placa escrita "Floresta Negra", o coelho checa seu mapa, se dá conta que está no lugar errado e diz "Eu sabia que deveria ter dobrado à esquerda lá em Albuquerque.." Aparece Göring e aponta a arma para o coelho, que surpreso, parece temeroso, mas logo recupera a confiança. Pernalonga o chama de velhinho e pergunta qual o caminho para Las Vegas. Göring se atrapalha na explicação e, num perspicaz jogo retórico, com total confiança, o próprio Pernalonga ensina ao alemão o caminho, que, em uma atitude inesperada, agradece e volta a marchar até se dar conta de que "Não tem Las Vegas em Alemanha!", com nítido sotaque alemão. Nesse momento, o próprio Pernalonga descobre que está na Alemanha e, temeroso, foge de volta para o buraco. As paixões novamente se invertem. Göring, readquirindo a confiança, usa sua arma como desentupidor para tentar puxar o coelho do buraco, enquanto a personagem sai por trás do alemão e utiliza seu famoso bordão "O que é que há, velhinho?".

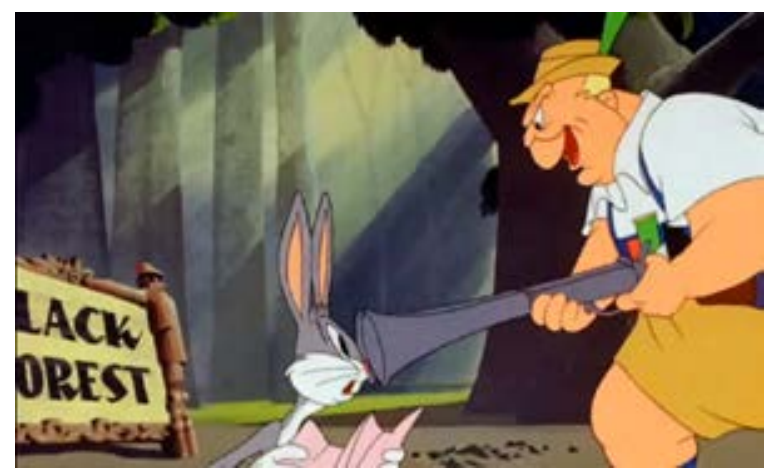

Figura 2: Göring aponta a arma para Pernalonga (1'27”)

Observamos, durante toda a animação, os efeitos patéticos do temor e da confiança. Nas palavras de Aristóteles, "são temíveis aquelas coisas que parecem possuir grande capacidade de arruinar, ou de causar danos que levam a grande desgosto. Por isso, até os indícios de tais coisas são temíveis, porque o temível 
parece estar próximo; é nisso, com efeito, que reside o perigo, a aproximação do temível" ${ }^{38}$

No desenrolar do enredo, as paixões se alternam como numa ópera, do temor nasce a confiança. Assim define o estagirita:

É que a confiança é o contrário do [temor; o que inspira confiança é o contrário do] temível, de sorte que a esperança é acompanhada da suposição de que os meios de salvação estão próximos, enquanto os temíveis ou não existem, ou estão distantes. O que inspira confiança é o distanciamento do temível e a proximidade dos meios de salvação. ${ }^{39}$

Na animação analisada, o "espírito dionisíaco" que representa a força vital, o excesso dos homens, configurou-se nas atitudes de segurança das personagens, nos momentos em que não temem seus antagonistas.

Na sequência, durante a perseguição, Pernalonga despreza as medalhas de Göring, entorta uma delas com os dentes, fato que induz o alemão a testar a outra, que também entorta. Aristóteles ${ }^{40}$ define o desprezo como "a atualização de uma opinião acerca do que não parece digno de consideração (com efeito, os males e os bens, cremos, merecem atenção, e também as coisas que tendem para eles, enquanto, todas as que são de valor nulo ou insignificante, consideramo-las indignas de atenção)", e distingue três espécies de desprezo: o desdém, a difamação e o ultraje. Pernalonga, ao constatar a imitação da medalha, desdenha o objeto, mas a crítica também recai sobre o próprio regime nazista, fica implícito que Hitler é um enganador. No original, Göring declara que elas são uma ersatz (palavra alemã que significa “imitação"), encolerizado, exclama: “odeio, Hitler, odeio o Reich, odeio chucrute, odeio tudo, adoro coelho, cenoura, é tudo o que amo, odeio, odeio, odeio Hitler". 


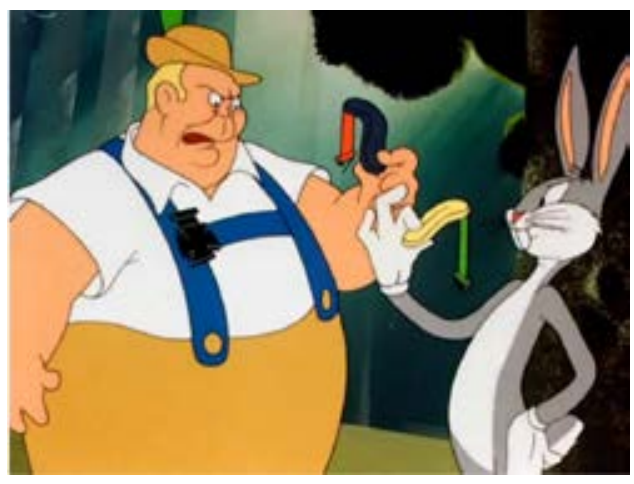

Figura 3: As falsas medalhas (2’40”)

A respeito do amor e do ódio Meyer ${ }^{41}$ afirma: “(...) o amor é recíproco para Aristóteles. Ele cria a paridade - mas o ódio, também, sem dúvida é recíproco. A distância entre os indivíduos se revela insignificante, o que afinal torna o amor e o ódio tão violentos”. Por isso, ao descobrir que fora enganado, Göring revoltase contra Hitler, o amor vira ódio, num arroubo violento de paixões, une-se ao inimigo. Ao desconstruir a imagem de Hitler, Göring cria seus próprios valores, que segundo a filosofia de Nietzsche seria o filosofar com o martelo.

Ao perceber a reação de Göring, Pernalonga se disfarça de Hitler, passa lama na orelha e boca para imitar o cabelo e o bigode, se arruma em um espelho que providencialmente se encontra pendurado em uma árvore. $\mathrm{O}$ alemão, temeroso, corre para se trocar e vestir seu uniforme nazista com todas as suas medalhas. Após a saudação nazista usual "Heil Hitler", o coelho começa a gritar palavras em um falso alemão, enquanto tira todas as medalhas do uniforme de Göring até arrancar seu cinto. Suas calças caem e mostram roupas de baixo de cor rosa, fato que constrange o alemão. Humildemente, tenta se explicar, se aproxima de Hitler (Pernalonga) e diz "eu beijo a mão do meu Führer, eu beijo a cara do meu Führer!" 42 A referência ao curta-metragem da Disney, mostra que o momento histórico uniu duas companhias rivais em prol de um bem maior: combater o nazismo.

Göring, por fim, exclama "Oh, eu sou um menino muito levado" (no original, uma mistura de inglês com falso alemão "Oh, I'm a bad flooten-boy-

41 Meyer, 2003, p. XLIV

42 "Eu beijo a cara do meu Führer" refere-se à música de mesmo título composta por Oliver Wallace que apresentava uma paródia do hino nazista, assunto principal de outro curta de animação da Disney de 1943, intitulado Der Fuehrer's Face (VAN RIPER, 2011) 
glooten!"). Nessa passagem, nota-se a transvaloração dos valores ${ }^{43}$ incitada pelas paixões do ódio e do amor. Göring reavalia sua crença ao desconstruir seus ídolos: Hitler e o Reich, e a declarar seu amor ao Pernalonga e à cenoura. A reconstrução do mito de Hitler é impulsionada pelo temor ao acreditar que está diante do Führer, que furioso o descompõe. Na atitude do suposto Hitler, evidenciamos o "espírito apolíneo", ligado aos ideais de harmonia e perfeição.

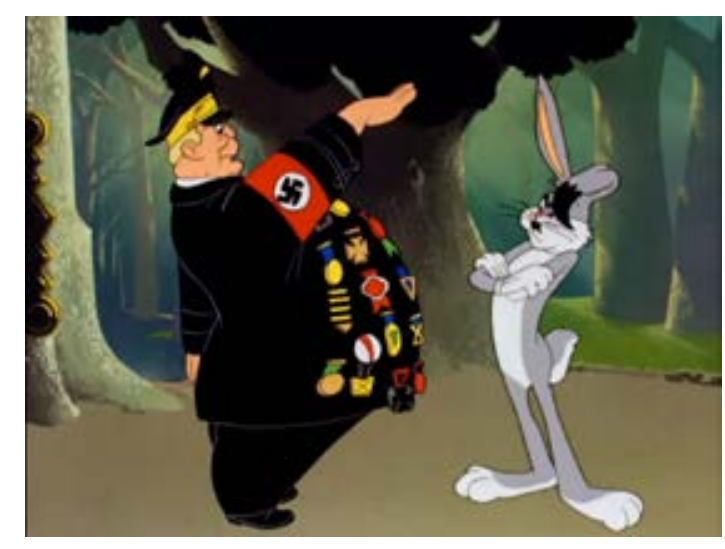

Figura 4: Pernalonga vestido de Hitler (3’02")

Após beijar Hitler (Pernalonga), Göring suja seu próprio rosto, que cria um falso bigode, olha-se no espelho e se confunde com Hitler, dizendo a saudação “Heil Hitler!”. Logo percebe o engano, e encolerizado se aproxima do coelho, que rapidamente se prepara para sua próxima investida. Dessa vez, se fantasia de Brünhilde - a famosa valquíria da mitologia nórdica, referência à ópera "Der Ring des Nibelungen" de Wagner, o compositor predileto de Hitler. Pernalonga cavalga um cavalo branco ao som do "Pilgrims Chorus" da ópera Tannhäuser. Göring reconhece a ópera e se veste de Siegfried - o herói que salva Brünhilde. Os dois dançam ao som de Johann Strauss II: "Vienna Life" e "You and You", essa última música originada da ópera Die Fledermaus (1874). Astucioso, Pernalonga bate com seu escudo no rosto de Göring, enganando-o mais uma vez.

43 O rompimento do homem ideal, pela tradição, para que se tenha o homem real. Este que não segue e sofre as consequências de não aderir aos valores impostos, isto é, não ter medo de ser tachado como imoral por não segui-los, visto que o conceito que se tem de "bem" e "mal" varia de uma pessoa para outra, ou seja, é subjetivo, cultural etc. (NIETZSCHE, 2014) 
A (des)construção do mito de Hitler: paixões aristotélicas e teorias nietzschianas em uma animação do pernalonga

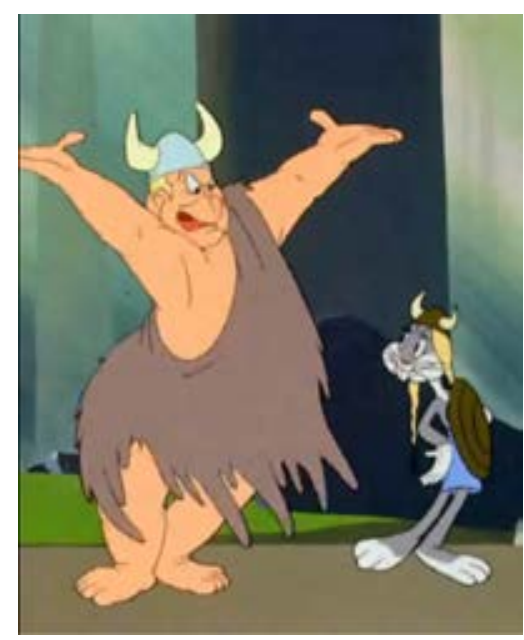

Figura 5: Göring e Pernalonga vestidos de Siegfried e Brünhilde (4'16”)

Ambos voltam às suas vestes habituais e Göring quer vingança, manda um gavião capturar Pernalonga. Desentendido com o sotaque alemão, o gavião mostra uma placa "Evidentemente esse cara é estrangeiro", e o alemão irritado repete "Oras, você sabe, coelho, coelho", tentando disfarçar o sotaque. Pernalonga aparece e ironicamente ajuda Göring ao se descrever para o gavião, que se aproxima e visualiza o coelho e parte para procurá-lo. Pernalonga, calmamente, mastiga sua cenoura enquanto pergunta para o alemão: "Você acha que ele vai me pegar, velhinho?". Göring afirma que claro que sim, "Ele vai te pegar antes que você possa dizer chucrute". Na dublagem original, Göring diz "Ele vai te pegar antes que você possa dizer Schicklgruber", sobrenome de nascença do pai de Hitler, Alois Schicklgruber.

Ao subestimar a inteligência do alemão, comparando sua expertise a de uma ave, evidencia-se um argumento baseado na estrutura do real. Segundo Cunha e Nhoque,

(...) os argumentos baseados na estrutura do real não se validam pelos aspectos racionais, e sim, nas próprias estruturas do real para estabelecer uma solidariedade entre os juízos admitidos e outros que se procura promover. Tais juízos estão ligados a fatos que se materializam no 
mundo real sob a forma discursiva e que permitem admitir, promover, ou não, acordos interacionais. ${ }^{44}$

$\mathrm{O}$ argumento ad ignorantiam, que evidencia a falta de profundidade no conteúdo do discurso, é nítido na interação verbal entre Pernalonga e o gavião que não consegue reconhecer um coelho descrito pelo próprio coelho. O mesmo argumento ocorre na indagação do Pernalonga, quando questiona Göring sobre o sucesso da missão do falcão: "Você acha que ele vai me pegar, velhinho?".

Na sequência do diálogo, Göring percebe que conversa com o coelho, que mais uma vez lhe supera, fazendo-lhe cócegas para despistá-lo. Pernalonga corre para o buraco e cai diretamente na armadilha do gavião, que o esperava no fundo do buraco com uma sacola. Göring pega a sacola com o coelho, corre em direção ao quartel-general de Hitler e encontra o Führer, que joga Paciência na frente de um mapa que marca o declínio das ocupações germânicas da "Festung Europa". ${ }^{45}$ Göring saúda "Heil Hitler" e o Führer responde "Heil mein", com o intuito de agradar Hitler (a reconstrução do mito), diz orgulhoso que capturou "Um coelhinho americano, Pernalongaheimer", utiliza um neologismo e assim, como no original, mescla a palavra alemã "weisenheimer" - "pessoa sábia" com o nome do coelho, sendo o original "Bugsenheimer Bunny", a junção do sufixo senheimer com Bugs Bunny, nome original do Pernalonga.

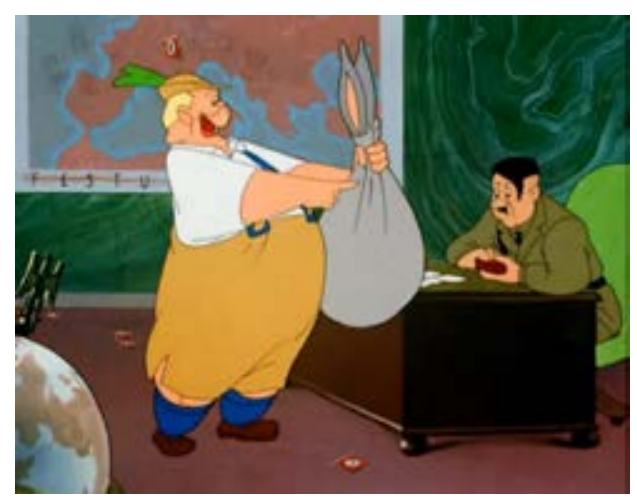

Figura 6: Göring e Hitler (6’35”)

44 Cunha; Nhoque, 2019, p. 151

45 "Festung Europa": áreas da Europa Continental ocupadas pela Alemanha nazista, enquanto os Aliados ocupavam o Reino Unido do outro lado do Canal (GILBERT, 1989) 
A (des)construção do mito de Hitler: paixões aristotélicas e teorias nietzschianas em uma animação do pernalonga

Hitler, orgulhoso de Göring, condecora-o com uma "Genuína medalha de ouro decorada com diamantes e outras pedras" pelo seu ato de heroísmo. O Führer, curioso, checa o conteúdo da sacola e grita em choque "Ach!! Himmel!", que significa “Ó!! Céus!”. Göring bisbilhota a sacola e também se espanta, repete as mesmas palavras de Hitler. O conteúdo da sacola que assustou tanto Göring como o Führer é revelado: Pernalonga caracterizado de Joseph Stalin. A animação termina com Pernalonga, que olha para a câmera e pergunta com sotaque russo: "Seu tabaco ter sabor diferente, não?". No original, "Seu tabaco anda com um gosto diferente?", frase do slogan do tabaco para cachimbo Sir Walter Raleigh. Nota-se na alusão ao tabaco americano, que é fumado por Stalin, a intenção de menosprezar Hitler e afirmar a aliança de Stalin com os Aliados.

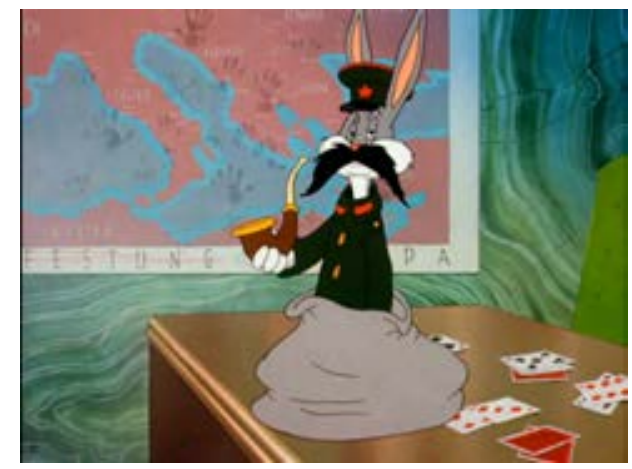

Figura 7: Pernalonga vestido de Stalin (7’04”)

Essas últimas cenas despertam várias paixões: a amabilidade de Hitler, a amizade de Göring, o medo de Hitler e Göring, a confiança do Pernalonga.

O final da animação é surpreendente: a chegada de Stalin desestabiliza até Hitler, que foge seguido por Göring, em uma alusão à derrota de Stalingrado, ponto crucial para a derrocada de Hitler na Segunda Guerra Mundial.

\section{Considerações Finais}

Convidamos o leitor a refletir sobre a afirmação de Ferreira:

Na emoção se manifesta a capacidade criativa do orador. O maior ou menor sucesso da argumentação está relacionado, também, com a maneira como os argumentos se organizam, com as palavras que se empregam, com o estilo menos ou mais formal em que se desenvolve. 
A lógica ou não do argumento pode até continuar a mesma, mas o revestimento das palavras em paixões constitui uma estrada de captação da atenção do auditório. ${ }^{46}$

Ferreira define com brilhantismo o resultado de nossa pesquisa, pois é o "revestimento das palavras em paixões" que conduz a adesão do auditório.

No início do capítulo, propusemos ao leitor uma viagem ao passado para analisarmos uma animação do Pernalonga. Percorremos algumas etapas antes de iniciarmos a análise. Em "Paixão, a etimologia”, apresentamos a peculiaridade da palavra "paixão" para melhor compreensão das "Paixões Aristotélicas"; em "Nietzsche, Ecce Homo", expusemos uma minibiografia do filósofo Nietzsche, que movido pelas paixões, construiu seu legado filosófico que sintetizamos em "Nietzsche, Ecce Philosophos"; em "Quem é o Pernalonga?" mostramos dados sobre a criação e importância da personagem, vista não apenas como entretenimento, mas como mascote da nacionalidade estadunidense durante a Segunda Guerra Mundial. Nossa análise em "Pernalonga: Um Breve Ensaio” nos conduziu a uma pesquisa histórica sobre os horrores de um planeta em guerra.

As animações do Pernalonga incitam ao riso, seu personagem, como já dissemos, foi inspirado em Charles Chaplin. No célebre texto, que na Antiguidade era conhecido como De Partibus Animalium (Das Partes dos Animais), Aristóteles afirma que o riso é o elemento que distingue o homem dos outros animais. O estagirita observava os aspectos fisiológicos do riso, ao analisar o diafragma. Segundo Jekovic"47: "Aristóteles ensina que o riso é algo próprio do homem. O senhor ri; logo, o senhor é um homem. Fez bem em rir, pois do contrário não nos teríamos apercebido disso". Portanto, Aristóteles não afirma categoricamente que "o homem é o único animal que ri", mas podemos concluir que o filósofo constatou a assertiva.

A respeito do riso, Bergson ${ }^{48}$ salienta que "para compreender o riso, é preciso colocá-lo em seu meio natural, que é a sociedade; é preciso, sobretudo, determinar sua função útil, que é uma função social (...). O riso deve corresponder a certas exigências da vida em comum (...) deve ter uma significação social".

Le Goff ${ }^{49}$ salienta que a persuasão, por meio do riso, vai além do instrumento da linguagem verbal, somam-se a ela a expressão facial, os gestos e a linguagem não-verbal que contribuem para a adesão do auditório.

\footnotetext{
46 Ferreira, 2010, p. 144

47 Jekovic, 1970, p. 47

48 Bergson, 2001, p. 6

49 Le Goff, 1990
} 
A (des)construção do mito de Hitler: paixões aristotélicas e teorias nietzschianas em uma animação do pernalonga

Enquanto analisávamos a animação do Pernalonga, o riso nos impulsionou, mas paradoxalmente, para desvendarmos a intencionalidade do texto, resgatamos o horror da Segunda Guerra Mundial. Surpreendeu-nos a liberdade de imprensa da época, 1945, em plena Guerra Mundial, uma animação apresentar um enredo no qual ridicularizava os principais personagens históricos de um partido nazista..$^{50}$

As imagens e sons, bem como o poder encantatório do cinema, nos proporcionaram a observação da proxêmica e da quinésica. As aproximações e os afastamentos se davam ora para intimidar, ora para alentar as personagens.

Em um mosaico de paixões, vimos despertar o temor, a confiança (que se inverteram durante toda a animação), a cólera, o desprezo, o ódio, o amor, paixões aristotélicas inerentes à alma humana, demasiadamente humana.

\section{Referências}

ARISTÓTELES. Retórica das Paixões. São Paulo: Martins Fontes, 2003.

ARISTÓTELES. Retórica. Introducción, traducción y notas por Quintín Racionero. Madrid: Editorial Gredos, 1994.

ARISTÓTELES. Retórica. São Paulo: Martins Fontes, 2012.

BERGSON, Henri. O riso: ensaio sobre a significação da comicidade. São Paulo: Martins Fontes, 2001.

BORDELOIS, Ivonne. Etimologia das Paixões. Tradução de Luciano Trigo. Rio de Janeiro: Odisseia Editorial, 2007.

CUNHA, Andreia; NHOQUE, Janete. A (des)constituição do ethos do professor pelas vias dos textos midiáticos. In: FERREIRA, Luiz Antonio (org.). Inteligência Retórica: o Ethos. São Paulo: Blucher, 2019.

ELLIS, William Ashton. Life of Richard Wagner - Volume 1. Londres: Kegan Paul, Trench, Trübner \& Com., LTD., 1904. p. 83-119.

ERNOUT, Alfred; MEILLET, Antoine. Dictionnaire étymologique de la langue latine. Paris: Klincksieck, 1939.

EVANS, Richad John. O Terceiro Reich em Guerra. São Paulo: Planeta, 2012.

FERREIRA, Luiz Antonio. Leitura e Persuasão - Princípios de Análise Retórica.

São Paulo: Contexto, 2010.

FRISCHAUER, Willi. The Rise and Fall of Hermann Goering. New York City: Ballantine Books, 1951.

GILBERT, Martin. A Segunda Guerra Mundial. Lisboa: Dom Quixote, 1989.

50 As animações para propaganda militar estadunidenses eram passadas para prisioneiros de guerra alemães com o intuito de desconstruir o mito de Hitler e do nazismo (WATERS et al., 2004) 
HALBWACHS, Maurice. A memória coletiva. Tradução de Laurent Léon Schaffter. São Paulo: Vértice/Revista dos Tribunais, 1990.

HASKEW, Michael. The Wehrmacht. London: Amber Books, 2011.

HASTINGS, Max. O mundo em guerra 1939-1945. Rio de Janeiro: Intrínseca, 2012.

HERR Meets Hare. Direção de Friz Freleng. Produção de Edward Selzer. Roteiro: Michael Maltese. Música: Carl W. Stalling. Califórnia: Warner Bros., 1945. (7 min.), son., color. Série Merrie Melodies.

HOMERO. Ilíada. Tradução de Christian Werner. São Paulo: Ubu, 2018.

INGLIS, Fred. Uma breve história da celebridade. Rio de Janeiro: Versal Editora, 2012.

JEKOVIC, Jerônimo. Duas ou três coisas que eu sei do humor. Revista de Cultura Vozes, Petrópolis, ano 64, vol. LXIV, n. 3, 1970.

LE GOFF, Jacques. História e memória. Tradução de Bernardo Leitão... [et al.]. Campinas, SP: Editora da UNICAMP, 1990. (Coleção Repertórios)

MASSON, Philippe. A Segunda Guerra Mundial: história e estratégias. São Paulo: Contexto, 2010.

MATOS , Olgária Chain Féres; CHAUÍ, Marilena de Souza. Nietzsche: vida e obra. In: NIETZSCHE, Friedrich Wilhelm. Obras incompletas. Seleção de textos de Gérard Lebrun. Tradução e notas de Rubens Rodrigues Torres Filho. São Paulo: Editora Nova Cultural, 1999. (Coleção Os Pensadores)NIETZSCHE, Friedrich Wilhelm. O caso Wagner: um problema para músicos; Nietzsche contra Wagner: dossiê de um psicólogo.; Tradução, notas e posfácio de Paulo César de Souza. São Paulo: Companhia de Bolso, 2016.

NIETZSCHE , Friedrich Wilhelm. Obras Incompletas. Seleção de Gérard Lebrun; tradução e notas de Rubens Rodrigues Torres Filho; posfácio de Antônio Cândido. São Paulo: Editora 34, 2014.

PATRIOTA, Rainer Câmara. Richard Wagner e o Romantismo Alemão. Princípios Revista de Filosofia. Natal (RN), v. 20, n. 34, p. 239-252, Julho/Dezembro de 2013.

PLATÃO. Crátilo. Tradução de Maria José Figueiredo. Lisboa: Instituto Piaget, 2001.

REBOUL, Olivier. Introdução à Retórica. 2. ed., São Paulo: Martins Fontes, 2004.

SANDER. Roberto. O Brasil na mira de Hitler: a história do afundamento de navios brasileiros pelos nazistas. Rio de Janeiro: Objetiva, 2007.

SANDLER, Kevin S. Reading the Rabbit: Explorations in Warner Bros. Animation. New Jersey: Rutgers University Press, 1998.

SHULL, Michael S.; WILT, David E. Doing Their Bit: Wartime American Animated Short Films, 1939-1945. Jefferson: McFarland \& Company, 2004.

TAYLOR, Telford. Sword and Swastika: Generals and Nazis in the Third Reich. New York: Barnes \& Noble, 1995.

THE NEW Encyclopaedia Britannica: Micropaedia. Chicago: Encyclopaedia Britannica, 1986. VAN RIPER, A. Bowdoin (ed.). Learning from Mickey, Donald and Walt: essays on Disney's edutainment films. Jefferson: McFarland \& Company, 2011.

WATERS, Michael R.; LONG, Mark; DICKENS, William. Lone Star Stalag: German Prisoners of War at Camp Hearne. College Station: Texas A\&M University Press, 2004. 